\author{
(online) $=$ ISSN $2285-3642$ \\ ISSN-L = $2285-3642$ \\ Journal of Economic Development, Environment and People \\ Volume 8, Issue4, 2019
}

URL: http://jedep.spiruharet.ro

e-mail: office jedep@spiruharet.ro

\title{
Critical Success Factors in IT Project Management. Case study on IT Banking Front-end IT System Project in Serbia
}

\author{
Marko Ranković ${ }^{1}$, Milena Ilić ${ }^{2}$, Miroslav Stojčić ${ }^{3}$ and Edita Kastratović ${ }^{4 \boxminus}$ \\ ${ }^{1}$ Fakultet za informacione tehnologije i inženjerstvo, Belgrade, SERBIA \\ ${ }^{2}$ Visoka škola strukovnih studija za informacione tehnologije- ITS, BelgradeSERBIA \\ ${ }^{3}$ Milšped Group, Belgrade, SERBIA \\ ${ }^{4}$ Visoka škola za poslovnu ekonomiju i preduzetništvo, Belgrade, SERBIA
}

\begin{abstract}
The success of project management in organizations depends on the context, that is, on type of organization, type of projects they implement, the environment and the conditions for the realization of projects. What matters to the textual issues of project success is due to a number of factors - type of project, importance for organization, resources, and the like. Insufficient number of organizations successfully managed to implement project manager procedures, while others met with a large number of problems, the resistance of employees first of all, ignorance, lack of resources, bad time management and other issues.

Organizations must have an incremental approach to the development and implementation of their project management methodologies, especially when it comes to implementing information technology project, that involve a great deal of human-work, innovation and usually cost a lot, development takes a long time, they are based on the knowledge of new technologies, and their success depends on the people who develop them, and those who will use those IT products and services.

This is a great challenge for management in terms of use of information technology, budget and planning, involvement of the project team and establishment of support from the environment.

Many IT projects are not implemented successfully because of poor application of project management procedures, lack of stakeholder support, absence of project sponsor etc.
\end{abstract}

Keywords: projects, project management, information technology, critical success factors, Front-end system implementation project

JEL Codes: M15, M21, 120, O22

How to cite: Ilic, M., Rankovic, M., Stojčić, M., \& Kastratovic, E. (2019). Critical Success Factors in IT Project Management. Case study on IT Banking Front-end IT System Project in Serbia. Journal of Economic Development, Environment and People, 8(4), 13-23. doi:http://dx.doi.org/10.26458/jedep.v8i4.637

Corresponding author. Tel.: + 381605522 581;

E-mail address: milena.ilic@its.edu.rs 


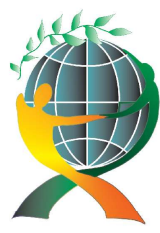

\author{
(online) $=$ ISSN $2285-3642$ \\ ISSN-L = $2285-3642$ \\ Journal of Economic Development, Environment and People \\ Volume 8, Issue 4, 2019 \\ URL: $\underline{\text { http://jedep.spiruharet.ro }}$ \\ e-mail: office jedep@spiruharet.ro
}

\title{
Introduction
}

According to the IPMA methodology, projects are divided into: military-defense projects, business projects and projects of organizational changes, communications system projects, special-event projects, then industrial plant projects, software projects and information systems introduction projects. Projects can also be international, developmental, media, product and service development projects, as well as research-and-development projects.

The project management concept encompasses negotiations management, project management goal setting, the project management organization defining, project scope management, time management, cost management, material resources management, human resources management, communications management, conflict management, quality management, change management, and risk management.

Risk management in IT projects involves the analysis of a large set of different data that is obtained based on the analysis of unsafe events of an IT project, then the likelihood of events, impact on business entity as well as the cause or effect of specific risk. [7]

Nowadays companies struggle with a very high competition, resources that are expensive and insufficient and also with employee demoralization due to the effects of economic crises, expensive technologies and other factors. [11] Information technology project are involved in a great deal of humanwork and innovation and cost a lot, lasts for a long time. The development and implementation of these projects are conditioned by the knowledge involved in their realization, that is, knowledge of technologies, the degree of innovation of the organization that will use the IT products / services. If the business entities use the practice of open innovation by producing a leverage effect, entities will focus their intellectual effort on creating new high technologies.[2] Also, for business entities that will use the IT products / services as part of IT projects development, is important to implement knowledge management. [3]

The paper presents project management in information technology industry, key issues and critical success factors of those projects. For this research article, implementation of two different IT projects in banking industry in Serbia during 2018 were observed according to Pinto criteria of success and new Model of Critical Success Factors in IT Project Management (Ranković - Ilić) which was developed for this special purpose.

\section{Project Management and Critical Factors for Project Success}

\subsection{Project management and projects}

Jovanović defines a project as "a complex unrepeatable business endeavour undertaken in the future so as to achieve goals in the predicted time and with predicted costs". [6]

The International Project Institute defined the standards and the principles for organizations and individuals, by which managers and organizations are provided with a help in their achievement of organizational goals. This global standard provides detailed understanding of program management and promotes efficient communication and coordination amongst different groups of project management. It emphasizes a full scope of program management and clarifies the supporting processes that bring the delivery of a program to organizations to an end. Organizations use the global standard as a tool for the assessment of the factors connecting projects within the framework of a single program and the allocation of resources among them. [12] 


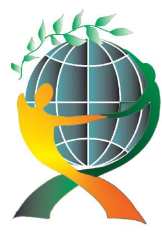

\author{
(online) $=$ ISSN $2285-3642$ \\ ISSN-L = 2285 - 3642 \\ Journal of Economic Development, Environment and People \\ Volume 8, Issue4, 2019 \\ URL: http://jedep.spiruharet.ro \\ e-mail: office jedep@spiruharet.ro
}

In the Republic of Serbia, a few educational institutions and one guild association conduct a formal and non-formal education of students and citizens in the field of project and program management. The Project Management Association of Serbia (YUPMA) has an important influence in the development of this discipline and in the provision of professional help to professionals and organizations. [15]

Project management implies the planning, control and management of different activities, and making business decisions. Jovanović considers that the next definition of project management (in a large number of other definitions) is optimal: "Project management represents a scientifically based and practically confirmed concept by which, with the help of appropriate methods of organization, planning and control, the rational harmonization of all needed resources and the coordination of conducting the needed activities are performed in order for a certain project to implement in the most efficient manner." [6]

The project management goal is the establishment of clear levels or authorities and decision-making, including the planning, influence and implementation of the project policies and activities. It includes the people, the policies and the processes that provide a framework within which project managers make decisions and undertake actions so as to optimize the outcomes in connection with their fields of responsibilities. This is achieved by defining and identifying the roles and responsibilities of all those involved in a project, including their interaction and the level of coordination with internal and external dependencies. [13]

\title{
1.2. Critical Factors for Project Success
}

There are ten critical success factors identified by Pinto and Slevin in their formulating the instruments of the Project Implementation Profile (PIP), namely: (1) the project mission/goal, (2) top management support, (3) project plans and timetables, (4) consultation with the client, (5) work, (6) technical tasks, (7) the client's acceptance, (8) monitoring and feedback, (9) communication, and (10) problem solving. [9]

A project mission, as the first factor, relates to the basic purpose of a project. The success of the project is expressed in the importance of the clear defining of goals, as well as the final benefits derived from the project. The project management initial phase frequently consists of a feasibility decision. The project mission relates to the state in which project goals are clear and understood, not only on the team, but also in the other departments of the organization. The project manager must deal with goal clarification, as well as with achieving a broader faith in the correspondence of the goals with the general organizational goals. [10]

Top management support, as the second factor, has long been considered to be very important in differentiating the final success and failure. Project managers and their teams depend on top management with respect to the authority, receiving guidelines and support. Apart from that, if a project is being developed for the purpose of the internal audience (inside the company), the degree of the management support in a project will lead towards substantial variations in the degree of the acceptance or rejection of that project or product. Top management support may include the aspects such as the allocation of the needed resources (funds, employees, time, etc.) as the assurance that the project manager will have the support of the top management in the case of a crisis. 


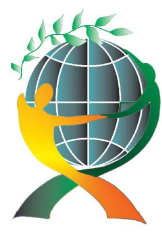

\author{
(online) $=$ ISSN $2285-3642$ \\ ISSN-L = $2285-3642$ \\ Journal of Economic Development, Environment and People \\ Volume 8, Issue 4, 2019 \\ URL: $\underline{\text { http://jedep.spiruharet.ro }}$ \\ e-mail: office jedep@spiruharet.ro
}

The third factor - project plans and timetables - refers to the importance of the development of a detailed plan of the phases needed in the implementation process. It is important to bear in mind, however, the fact that the activities in connection with a project planning and its timetable differ. Planning, which is the first and more general step in the development of a project implementation strategy, consists of the determination of the scope, the creation of the WBS, as well as the allocation of resources and the assignment of activities. Making a timetable implies the determination of deadlines and turning points for every important element of a project in general. Project plans and its timeline as a factor are concerned with the degree to which timelines, turning points, the effort and equipment are determined. There must be a satisfactory measuring system which assesses the realistic performance as opposed to budgetary disbursements and timelines.

Consultation with the client is the fourth factor. The "client" is anyone who will ultimately use the product of the project, either as a client outside the company or as a department inside the organization. The need for consultations with the client has increasingly been considered as important in an attempt to create the system implementation. Certainly, the level to which clients are personally involved in the implementation process is directly connected with variations in their support to the project. It is important that clients should be identified for the project and that whether, or not, their needs have been met should be correctly determined, i.e. their satisfaction should be ensured. [16]

The fifth factor, human resources, implies recruiting, selecting, and training the members of the team who will be working on a project. The important, although often overlooked, aspect of the implementation process also concerns the nature of the human resources included in the project. In many situations, team members are selected without gaining a full insight into the skills needed for making an active contribution to a more successful implementation. The question of human resources in a project concerns the development of the implementation team that has the ability and dedication to their roles. [10]

Technical tasks, as the sixth factor, relate to the necessity of having not only the required number of employees for the implementation team, but also of ensuring that they have the technical skills and the technical-technological support need for them to perform their respective tasks. It is important that the persons leading the project should understand the technology included in the project. Besides, adequate technology must be in place so that it could support the system. Without the necessary technology and technical skills, projects quickly disintegrate into a series of wrong interpretations and technical mistakes.

The seventh factor, the client's approval, relates to the final phase in the project development process, when the general efficiency of the project is determined. Together with consultation with the client in the earlier phases of the system implementation process, it is crucially important to determine whether the client for whom the project commenced in the first place will also accept that project. Too frequently, it happens that project managers make a mistake by believing that the client (either internal or external for the organization) will accept the system obtained if they perform the other phases of the implementation process well. Actually, the client's approval is the phase in the lifecycle of the project which must be managed in the same manner as it is done with any other phase. [10]

The eighth factor, supervision and feedback, relates to the project control process which, at the end of each phase of the project implementation, the key employees receive feedback on how the project is progressing in comparison with the initial predictions. Enabling adequate supervision mechanisms and 


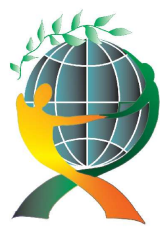

\author{
(online) $=$ ISSN $2285-3642$ \\ ISSN-L = $2285-3642$ \\ Journal of Economic Development, Environment and People \\ Volume 8, Issue4, 2019 \\ URL: $\underline{\text { http://jedep.spiruharet.ro }}$ \\ e-mail: office jedep@spiruharet.ro
}

feedback enables the project manager to predict problems, oversee corrective measures, and ensure that not one single deficiency has been overlooked.

Communication, as the ninth factor, is not only essentially important to the project team themselves, but it is also vital to the stakeholders' management between the team and the rest of the organization, as well as clients. Communication also relates to the feedback mechanisms and the necessity of the exchange of information with both clients and the rest of the organization when the project possibilities and goal, changes in procedures, reports on the status, etc. are concerned.

Problem solving is the tenth, and the last, factor of this model. Problematic fields are present in almost every development of a project. The measure of a successful project is not problem avoidance, but it is rather making right steps once a problem has occurred. Irrespective of how carefully implementation is planned, it is impossible to predict every problematic field or a problem that might occur. As a result of that, the project manager must include the mechanisms for problem recognition and their solving once they appear. Such mechanisms not only facilitate reacting to the occurrence of a problem, but they also make the prediction and possible prevention of potential problematic fields in the implementation process easier. [7]

\title{
2. Projects in the Field of Information Technologies
}

The criteria for the success of IT projects are often unclear and deprived of strict guidelines on success in a project. In 1992 and in 2003, two researchers, W. DeLone and E. McLean, analyzed several previous studies on IT projects so as to identify the key success indicators. [4] Their findings indicate that IT projects should at least be valued in accordance with six criteria: [10]

- the quality of the system: A project supply system must be able to ensure clients that the implemented system will be operating as it should. All systems must meet certain criteria, so, for example, they should be simple to use and ensure quality information.

- $\quad$ the quality of information: The information generated by the system must be the information based on the data obtained from the user(s) and of a sufficient quality so as to be effective. In other words, the generated information should not require additional information and data sorting. The system users must see the quality information it produces.

- $\quad$ the use: Once implemented, the IT system must be used. It is obvious that every IT system is as important as it is good in problem solving, as well as the mechanism for making decisions and the network mechanism. The use criterion assesses the real usage of the system by determining the degree to which the same is used by buyers.

- $\quad$ user satisfaction: Once the system is completed, the team must determine user satisfaction. One of the best questions in assessing IT projects is whether the success has to do with the determination of user satisfaction with the system. Yet, due to that fact, the client is ultimately the judge and he is the one to decide whether the project is efficient or not. It is necessary to reach a certain degree of client satisfaction 


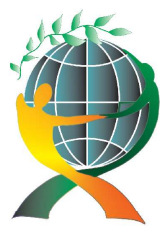

\author{
(online) $=$ ISSN $2285-3642$ \\ ISSN-L = $2285-3642$ \\ Journal of Economic Development, Environment and People \\ Volume 8, Issue 4, 2019 \\ URL: http://jedep.spiruharet.ro \\ e-mail: office jedep@spiruharet.ro
}

with the system itself and its outputs, i.e. the results and effects of its operation. Also, during the transfer of IT projects to buyers, it is customary for them to experience initial confusion regarding the characteristics of the final product, or to understand them in wrong way. There are buyers who will deliberately refrain from accepting the project unconditionally since they are afraid that, after they have approved of it, they will lose the ability to require changes or corrections due to obvious errors. Finally, depending on how close a communication the project team was maintaining with the client during the development of the project, the final product may, but does not have to, be what the buyer actually wants. [10]

- the individual influence: All systems should be simple to use and ensure quality information; but, apart from meeting these needs, there is a special criterion for the determination of the usefulness of the system ordered by the client. Is decision-making faster and more precise? Does the system offer more information? Is such information more accessible or more easily assimilated? In brief, is the system useful to the users in the manner important to them?

- the organizational influence: Finally, the system supplier must be able to determine whether there are positive impacts throughout clients' organizations, i.e. if, for example, there is a collective or synergetic effect on the corporation of clients, or not; if the system in place has a good impact, or if there are financial or operational metrics indicating the efficiency or quality of the system, or not?

\title{
3. Implementation of IT Projectsin Serbian Banks (Analysis of Successfully Implemented IT System Project)
}

Banks are the most important constituents of the financial structure of a country and even more they represent nations financial backbone and valuable measure of economic perspective of one nation. [1]

The banking system of the Republic of Serbia consists of the central bank (National Bank of Serbia) and commercial banks. Commercial banks conduct their business independently, in order to make profit on the principles of solvency, profitability and providing liquidity.

In recent years, there has been a marked competition in banking market in Republic of Serbia and a constant search for banks for business models that can provide them with long-term business success. Innovation is being implemented in all segments of banking, and the development of models and strategies is a priority at all levels of management in today's banks. [14] Banks often implement IT projects in order to be costumer oriented.

IT projects in banking can be divided into projects of implementation of Front-end systems, that is, IT systems aimed at end users of banking services and projects of implementation of Back-end systems, that is, those projects related to banking IT infrastructure, which includes different processing systems banking data, risk analysis, regulatory requirements. Valuation of a project according to the six criteria defined by Pinto [10] should be viewed through the prism of specificity of IT projects in banking. These criteria have 


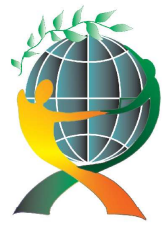

\author{
(online) $=$ ISSN $2285-3642$ \\ ISSN-L = $2285-3642$ \\ Journal of Economic Development, Environment and People \\ Volume 8, Issue4, 2019 \\ URL: http://jedep.spiruharet.ro \\ e-mail: office jedep@spiruharet.ro
}

several other dimensions through which they "shed light" on internal and external stakeholders, and these dimensions are trust, security and time. The project of implementation as part of the Front-end system was implemented using Agile project methodology. Empiric research were conducted based on one author's participation, two authors' observation, case study analysis, as well as description, induction and deduction.

For this research article, implementation of one IT projects in banking industry in Serbia during 20182019 were observed (without specifying customer identification information) according to Pinto criteria of success and new Model of Critical Success Factors in IT Project Management (Ranković - Ilić) which was developed for this special purpose. Ranković-llić model defines combined list of the criteria for Success which includes basic category:

1. Project successfulness valuation criteria;

2. Quality prism;

3. Trust and the system quality;

4. Security and the system quality;

5. Time and the system quality.

Project successfulness valuation criteria involves the quality of the system, the quality of information, the use, user satisfaction, the individual influence, the organizational influence.

Quality prism involves trust, security and time.

Trust and the system quality involves criteria such as trust and the quality of information, trust and the use, trust and user satisfaction, trust and the individual influence, trust and the organizational influence.

Security and the system quality group of criteria involves security and the quality of information, security and the use, security and user satisfaction, security and the individual influence as well as security and the organizational influence.

At the end, Time and the system quality group of criteria involves time and the quality of information, time and the use, time and user satisfaction, time and the individual influence, time and the organizational influence.

The analyzed IT project, the Front-end system implementation project was implemented with an Agile project management methodology to provide the bank's end-users with the best possible user experience in working with the bank's Front-end applications. The final beneficiaries were involved in the qualitative evaluation of each of the iterations and based on their feedback, the course of further realization of the project was directed. 


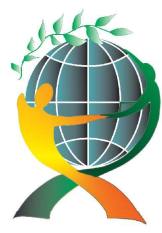

\author{
(online) $=$ ISSN $2285-3642$ \\ ISSN-L = 2285 - 3642 \\ Journal of Economic Development, Environment and People \\ Volume 8, Issue 4, 2019 \\ URL: $\underline{\text { http://jedep.spiruharet.ro }}$ \\ e-mail: office jedep@spiruharet.ro
}

The qualitative assessment of the project implementation was performed according to the performance criteria, and through the prism of specific quality criteria defined in the model such as trust, security and time. Trust was analyzed through the criterion of trust and quality of the System, Trust and quality of information, trust and use, Trust and satisfaction of users, trust and individual influence, trust and organizational influence.

In terms of quality as a result of implementation (the criterion of trust and the quality of the System) in the case of the first project, it looks at the extent to which the system can meet the needs of end users, and therefore, at the end of each iteration, end users are surveyed about the level of quality and trust gained during testing. of each iteration. The results obtained from the survey have always been better than the previous ones.

In terms of trust and quality of information, as it is an IT system that processes and presents sensitive financial information, it is important that it is of high quality and that the end user believes in it. In this case, the end users were also interviewed at the end of each iteration about the level of quality and confidence in the information presented to them during the testing of each iteration. Also, each member of the control group had a key to validate the information, which ensured that the control group members were satisfied with the quality of information as well as their confidence in the quality of the system and the output information.

In terms of trust and use as a criterion, the combination of the two criteria led to the rapid and extensive use of the bank's application systems, while the beneficiaries cited trusts as the most important criterion for choosing a particular system.

With regard to trust and customer satisfaction, it started with the thesis that customer satisfaction is viewed through the prism of trust, that is, the banking IT system will meet the needs of end users in a perhaps predictable but certainly reliable way. The second thesis is that if the system meets the needs of clients, then it is successfully implemented. Also, in this part, end users were surveyed, and the results of the survey showed in each iteration an increasing level of confidence in the ability of the banking IT system to meet their needs.

In terms of Trust and Individual Impact, the measurement of this impact has been viewed through the impact on the beneficiary on the one hand, as well as the impact on individuals within the organization. Through the mass of the phenomenon, looking at the impact on customers, the results of the implementation of the first IT project are more visible, and if everything is viewed through the prism of trust, every individual opinion is important because it has an impact on other users and the results of the bank's business operations. When analyzing the impact on individuals within the bank (employees), then their trust in the IT system is important in order to create a customer-focused organization. 


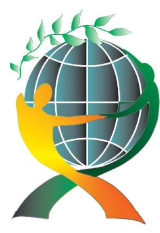

\author{
(online) $=$ ISSN $2285-3642$ \\ ISSN-L = 2285 - 3642 \\ Journal of Economic Development, Environment and People \\ Volume 8, Issue4, 2019 \\ URL: http://jedep.spiruharet.ro \\ e-mail: office jedep@spiruharet.ro
}

In terms of trust and organizational influence, the IT system has created a climate of trust in the bank and the best lawyers of this implemented application are banks employed.

Security as a group of criteria was analyzed through: security and quality of the System; Information Security and Quality, Security and Use, Security and Customer Satisfaction, Security and Individual Impact, and Security and Organizational Impact.

In terms of system security and quality, the following were used as standards for the implementation of the System: Payment Card Industry Data Security Standard (PCI DSS), [8] and ISO 27001 standard[5], and the banking IT system in question was fully implemented in accordance with the requirements of these standards.

In terms of security and quality of information, the success of meeting this criterion was measured by the results of tests of specialized companies that tested the possibilities of influencing the quality of information.

In terms of security and use, end users have tested different authentication capabilities at each iteration, as well as its impact on future system utilization capabilities.

In terms of Customer Safety and Satisfaction, the bank has provided security for the System to be implemented.

In terms of security and individual impact, the impact on the end user of the project implementation results as well as on the bank employees has been observed. The results of the implementation of security measures in this system are important from the aspect of security of sensitive end-user financial data. Also, in terms of impact on employees, this is a mandatory way of working at a bank.

Security and organizational influence are important for positioning the bank in the awareness of clients and creating trust in the bank.

Time as a group of criteria was measured through Time and quality of the System; Time and quality of information, Time and use; Time and customer satisfaction; Time and individual influence and time and organizational influence.

When it comes to the time and quality of the System, the time of the system implementation, the response time of the System and the time of implementation of the System changes were observed.

In terms of Time and quality of information, end users tested the speed of the System at the end of each iteration and showed satisfaction with it. 


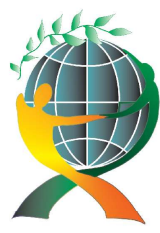

\author{
(online) $=$ ISSN $2285-3642$ \\ ISSN-L = $2285-3642$ \\ Journal of Economic Development, Environment and People \\ Volume 8, Issue 4, 2019 \\ URL: $\underline{\text { http://jedep.spiruharet.ro }}$ \\ e-mail: office jedep@spiruharet.ro
}

For the Time and Use criteria, end-users and users in the iterative tests tracked the time of realization of the initial approach, change of data, realization of transactions and reporting as different functional units and evaluated each one positively.

Time and user satisfaction brought a clear link between time and user satisfaction, which created a positive result in terms of better optimization of each subsequent iteration.

Time and individual impact were viewed from the end-user perspective as well as time and organizational impact. Implementation as a quality criterion was completed on time and is a condition for the applicability of the project in post-production exploitation.

\title{
4. Conclusion
}

The paper analyzes banking IT Project viewed from the angle of success by the criteria defined by Pinto - for successful implementation of IT projects - and through the prism of qualitative criteria identified by the authors as extremely important for the implementation of projects in the banking industry (Ranković - Ilić model). The project was successfully implemented on the basis of qualitative analysis of results and defined performance criteria (special quality criteria).

The method of case study analysis, observation, observation with participation, as well as the method of descriptive, induction and deduction, led to empirical research and conclusions outlined in this scientific article.

\section{References}

[1] Abirami K, Indian Public Sector Banks - performance analysis. VOLUME-8, ISSUE-5, MAY-2019 • PRINT ISSN No. 2277 - 8160, URL: https://www.worldwidejournals.com/global-journal-for-research-analysisGJRA/recent issues pdf/2019/May/May 2019 1557745871 0212540.pdf

[2] Arsenijevič, O.M., Orčič, D., Kastratović, E. (2017). Development of an optimization tool for intangibles in SMEs: A case study from serbia with a pilot research in the prestige by Milka ccmpany. Optimal Management Strategies in Small and Medium Enterprises. Avilable at: https://www.scopus.com/authid/detail.uri?authorld=55421212600 (2.8.2019)

[3] Braicu, C., Bucea-Manea-Tonis, R., Bucea-Manea-Tonis, R., (2017). Knowledge management based on expert systems. Proceedings of the 30th International Business Information Management Association Conference, IBIMA 2017 - Vision 2020: Sustainable Economic development, Innovation Management, and Global Growth, URL: https://ibima.org/accepted-paper/knowledge-management-based-expert-systems/

[4] DeLone, W. H., McLean, E. R. (1992). Information systems success: The quest for the dependent variable. Information Systems Research, 3(1): 60-95;

[5] ISO 27001 standard at International Organization for Standardization, URL: https://www.iso.org/isoiec-27001information-security.html

[6] Jovanović, P. (2010). Upravljanje projektima. Beograd: Visoka škola za projektni menadžment. p. 19. 


\author{
(online) $=$ ISSN $2285-3642$ \\ ISSN-L = $2285-3642$ \\ Journal of Economic Development, Environment and People \\ Volume 8, Issue4, 2019 \\ URL: http://jedep.spiruharet.ro \\ e-mail: office jedep@spiruharet.ro
}

[7] Mia Torres-Dela Cruz | Subashini A/P Ganapathy | Noor Zuhaili Binti Mohd Yasin "Knowledge Management and Predictive Analytics in IT Project Risks" Published in International Journal of Trend in Scientific Research and Development (ijtsrd), ISSN: 2456-6470, Special Issue I International Conference on Advanced Engineering and Information Technology, November 2018, pp.209-216, URL: https://www.ijtsrd.com/papers/ijtsrd19142.pdf

[8] Payment Card Industry Data Security Standard (PCI DSS) at Official PCI Security Standards Council Site, URL https://www.pcisecuritystandards.org/

[9] Pinto, J. (2015). Project Management Achieving Competitive Advantage. Third Edition. Pearson.

[10] Pinto, J. K., Slevin, D. P. (1987). Critical factors in successful project implementation, IEEE Transactions on Engineering Management, EM-34.

[11] Pistol, L., Bucea-Manea-Tonis, R. (2017). Resource productivity in a circular economy. Proceedings of the 30th International Business Information Management Association Conference, IBIMA 2017 - Vision 2020: Sustainable Economic development, Innovation Management, and Global Growth, URL: https://ibima.org/acceptedpaper/resource-productivity-in-a-circular-economy/

[12] $\mathrm{PMBOK}^{\circledR}$ Guide - Sixth Edition, dostupno na: Project Management Institute https://www.pmi.org/ 17. 03.2019.

[13] Ranković, M, Ilić, M. (2018). Upravljanje projektima. Visoka škola strukovnih studija za informacione tehnologije, ITS - Beograd.

[14] Sead Jatić, \& Ilić, M. P. [2018]. Tradicionalni i novi poslovni modeli u bankarskoj industriji. Bankarstvo, 47(1), 106117.

[15] YUPMA - Serbian Project Management Association http://yupma.org.rs/en/ (22. 03. 2019).

[16] Živković, R., Stanković, J., Ilić, M., Gajić, J. (2014). Istraživanje satisfakcije potrošača o kvalitetu usluga javnih komunalnih preduzeća grada Beograda. Marketing, 45(3), 179-186. 